\title{
J31 非一様流中でのDME扡散火炎の自着火及び消炎特性に関する研究 Experimental study of autoignition and extinction of DME diffusion flames in nonuniform flows
}

\author{
$\bigcirc$ 学 梅田結 (大分大学院), 学 三重野涉 (大分大学院), 学 宮原朋広 (大分大学院) \\ 正 田上公俊 (大分大学), 正 嶋田不美生（大分大学） \\ Junji Umeda, Oita Univ. Wataru Mieno, Oita Univ. Tomohiro Miyahara, Oita Univ. \\ Kimitosi Tanoue, Oita Univ. Fumio Shimada, Oita Univ. \\ Key Words : DME, Autoignition, Extinction, Diffusion Flame
}

\section{1. 緒論}

現在の内燃機関の設計は，地球環境問題とエネルギー 資源枯渴問題から，低公害なエネルギ一燃料の利用と高 効率な燃焼技術が求められている(1) (3). 軽油代替燃料と して，注目されているジメチルエーテル（以下，DMEと 示す）性も低分子のエーテルであり，毒性もメタノ一

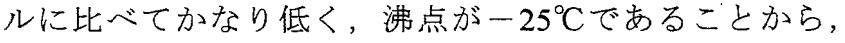
早い混合気の形成, 着火遅れの低減, 良好な始動特性を 有し，さらにセタン価が55から60であることから，ディ 一ゼル燃料として良好な自着火特徽(4) (6) 有する。また， 含酸素燃料で炭素同士の結合がないことから無煙な燃焼 であり，同時にEGRによる燃焼温度制御により $\mathrm{NO}_{\mathrm{x}}$ の削 減も期待できる.

一般に,ディーゼル機関内の燃焼は拡散燃焼が支配的と されるため，DMEを実機に適用する場合，その拡散然焼 特性を把握する必要がある。そこで, 本研究では対向流 バーナによる実験と数值計算により非一様流中でのDME 火炎の基礎的な着火及び消炎特性を調べる。ここでは燃 焼温度, 不活性ガス種, 火炎構造, 火炎伸張などが着火 及び消炎特性にどのような影響を及ぼすかを実験的に調 べると共に, 詳細化学反応を用いた数値計算と比較して, 反応機構の妥当性を検証する。

\section{2. 実験装置および方法}

\section{1 対向流バーナ実験装置および実験方法}

本研究で使用する対向流バーナ実験装置は，過去の研

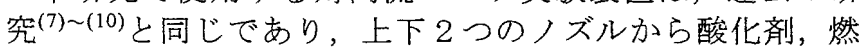
料が噴射され，バーナ上部と下部の間によどみ面を形成 し，対向流火炎を形成する装置である。

実験 I では上下のノズルから酸化剂，燃料を噴出し火 炎を形成後，火炎伸張を変化させながら火炎を観察し， 消炎する条件を特定した，また，実験 II，IIIでは酸化剤 と然料を流した状態でバーナの温度を上げていき，着火 する酸化剂温度を観察した。

\section{2 火炎伸張率}

本研究で用いる火炎伸張率 $a_{2}{ }^{(11)}$ を次のように表す.

$$
a_{2}=\frac{2\left|V_{2}\right|}{L}\left(1+\frac{\left|V_{1}\right| \sqrt{\rho_{1}}}{\left|V_{2}\right| \sqrt{\rho_{2}}}\right)
$$

ここで，Vは流速， $\rho$ は流体の密度である，添字 1,2 は それぞれ酸化剤，燃料を示す。Lはトップとボ卜ムの管 の間隔である，本研究ではトップとボトムの管の間隔は 実験 I では $L=8 \mathrm{~mm}$, 実験 II， IIIでは $L=10 \mathrm{~mm}$ にした. また，上下の流体の運動量を揃え，よどみ面がバーナ間 つ中心にできるようにするために, $\rho_{1} V_{1}^{2}=\rho_{2} V_{2}^{2}$ としている。 2.3 火炎パラメータ

火炎構造の指標になる mixture fraction $Z$ は次式で示され る.

$$
Z=\frac{Y_{F} / W_{F} v_{F}+\left(Y_{O,-\infty}-Y_{O}\right) / W_{O} v_{O}}{Y_{F, \infty} / W_{F} v_{F}+Y_{O,-\infty} / W_{O} v_{O}}
$$

このとき， $Z$ は mixing layer 内の相対位置を示し，酸化剂 側で 0 ，燃料側で 1 となる。ここで, $Y$ は質量分率, Wは 分子量, $v$ はストイキのモル数である. 添字 $\mathrm{O}, \mathrm{F}$ は酸化 剂, 燃料を表す.酸化剂ノズル出口での質量分率を $Y_{\mathrm{O},-\infty}$, 燃料ノズル出口での質量分率を $Y_{\mathrm{F}, \infty}$ とする.また, 火炎位 置は以下の Stoichiometric mixture fraction $Z_{\mathrm{st}}$ で特徵付けら れる(12)

$$
Z_{s t}=1 /\left(1+\frac{Y_{F, \infty} \cdot W_{O} \cdot v_{O}}{Y_{O,-\infty} \cdot W_{F} \cdot v_{F}}\right)
$$

\section{4 数値計算手法}

本研究では，数值計算手法として西岡らが開発した 1 次元対向流火炎の計算コード(13)を使用した。本コードは Sandia National Laboratories で開発された CHEMKIN ${ }^{(14)}$ の サブルーチンを使い詳細な化学反応機構を用いた解析を 行うことができる. 本研究では本コードを用いて Flame-Controlling Continuation method のより消炎条件を特 定した。支配方程式, 解法などの詳細は文献(13)を参照. 支配方程式中のDMEの反応機構はCUrran らの詳細反応機 構 ${ }^{(15)}$ を使用した。 また, 火炎温度の算出のための平衡計 算には Reynoldsなどによって開発された STANJAN に基

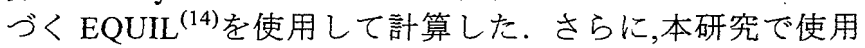
した各熱物性および輸送係数は CHEMKIN ${ }^{(14)}$ から算出し た.

\section{3. 実験および考察}

\section{1 消炎に及ぼす不活性ガス種の影響(実験 I)}

本研究ではまず，消炎に及ぼす不活性ガス種の影響を 調べるため， $\mathrm{DME} と \mathrm{C}_{3} \mathrm{H}_{8}$ 用いて火炎温度を一定にし， 火炎構造を変化させる消炎実験を行った。本研究ではま ず，燃料側に $\mathrm{N}_{2}$ を添加し，断熱火炎温度を減少させた基 準混合気を作成した。断熱火炎温度はDMEでは $T_{\mathrm{ad}}=2050 \mathrm{~K}$, $\mathrm{C}_{3} \mathrm{H}_{8}$ では $T_{\mathrm{ad}}=2152 \mathrm{~K}$ とした。基準混合気に対して火炎温度 一定にし， $Z_{\mathrm{st}}$ を変化させるため, 各混合気の組成を保持 したまま, 酸化剂側と燃料側の窒素量を調節し, その他 の燃料組成を決定した。またこのときの火炎温度と等 しくなるように $\mathrm{N}_{2}$ を $\mathrm{CO}_{2}$ に置換し, 添加した場合も測定し t.

図 1 に消炎実験における，消炎時の断熱火炎温度 $T_{\mathrm{ad}}$ と消 炎時の火炎伸張率 $a_{2, \mathrm{E}}$ の関係を示す。図加占，両然料とも 添加する気体に関係なく火炎温度の増加に伴い消炎時の 火炎伸張率が増加することが分かる. 火炎伸張が増加す ると, 酸化剂と燃料の濃度勾配が増加し, 火炎近傍での 拡散時間が減少する。化学反応時間を一定とすると，両 者の比で定義されるダムケラ一数は減少し, 消炎に至る. このような非平衡現象を表すパラメータとして，スカラ 一消散率が定義されている，火炎伸張が増大すると， ス カラー消散率も増加すると考えられることから，消炎時 の拡散特性時間の短い, 即ち, スカラー消散率や火炎伸 
張率功大きい火炎ほど消炎しにくい火炎といえる。また， $\mathrm{CO}_{2}$ を添加した火炎の方が $\mathrm{N}_{2}$ を添加した火炎に比べ, 両然 料とも火炎温度は同一であるのに, 消炎時の火炎伸張率 は高くなっている.このことから， $\mathrm{CO}_{2}$ の添加により耐消 炎特性が向上したことが分かる。これは $\mathrm{CO}_{2}$ で布釈するこ とで混合気の温度伝導率が低下し，火炎伸張を受けた場 合の温度低下が少なくなるためと推察される。

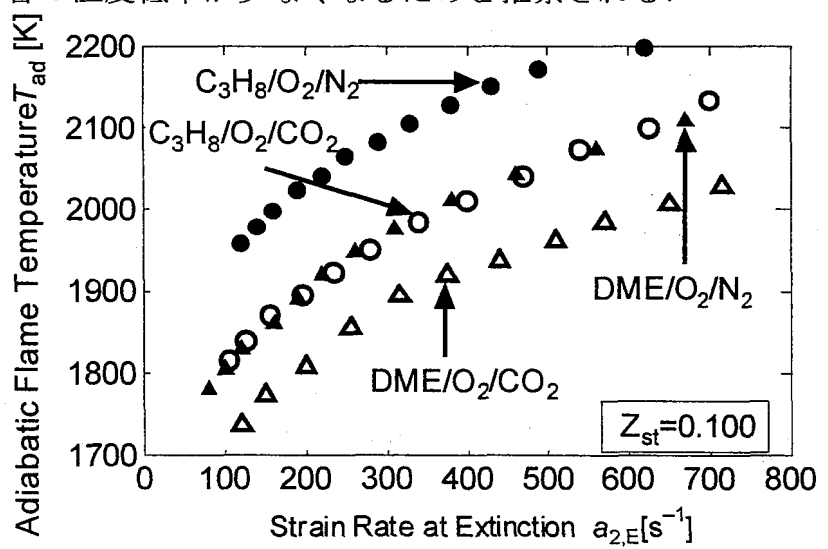

Fig.1 Adiabatic flame temperature as a function of the strain rate at extinction, for $\mathrm{CO}_{2}$ diluted flames.

\section{2 着火に及ぼす燃料質量分率の影響(実験 II)}

次に本研究では火炎伸張を一定にし，然料質量分率を 変化させ，着火における燃料質量分率の影響を調べた。

酸化剤には空気, 燃料には DME と $\mathrm{C}_{3} \mathrm{H}_{8}$ を用い，火炎伸 張は $a_{2}=150\left(\mathrm{~s}^{-1}\right)$ で一定とした. 質量分率は燃料に $\mathrm{N}_{2}$ を添 加することで変化させた．

図2に着火時の空気温度と燃料質量分率の関係を示す。 両燃料とも燃料濃度が増加するにつれて着火しやすくな っているのが分かる.また, 同一然料質量分率のときDME より $\mathrm{C}_{3} \mathrm{H}_{8}$ のほうが着火しやすいことが分かった。一般に $\mathrm{C}_{3} \mathrm{H}_{8}$ よりDMEの方が自着火温度が低いことが知られてい るが，非一様流中では拡散の影響により $\mathrm{C}_{3} \mathrm{H}_{8}$ が着火しや すい結果となった。

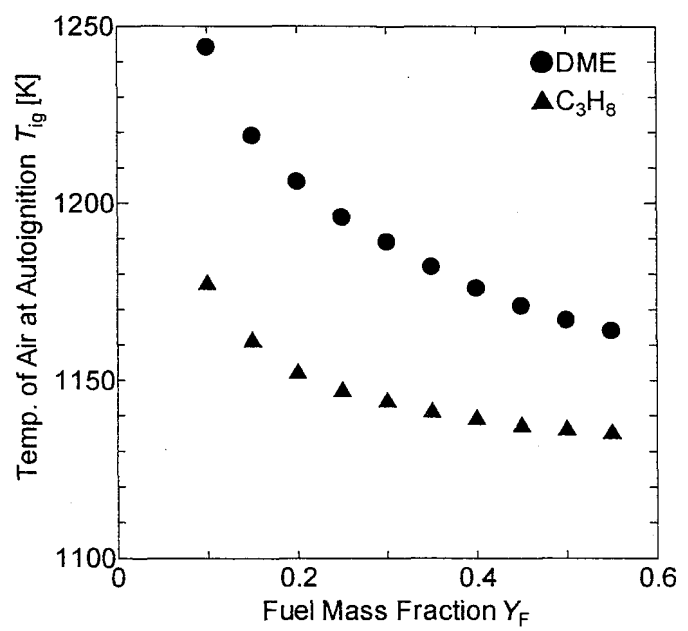

Fig.2 The temperature of air at autoignition as a function of the fuel mass fraction, $Y_{\mathrm{F}}$, at a fixed strain rate of $a_{2}=150 \mathrm{~s}^{-1}$.

3.3 着火に及ぼす火炎伸張の影響(実験III)

さらに， $\mathrm{DME}$ と $\mathrm{C}_{3} \mathrm{H}_{8}$ を用いて燃料モル分率を $X_{\mathrm{F}}=0.15$ に 固定し，火炎伸張による着火の影響を観察した。

図3に着火時の空気温度と火炎伸張の関係を示す。 $\mathrm{C}_{3} \mathrm{H}_{8}$ に関する今回の実験值とHumerらのデータ(7)と比較する と定性的に一致しているため, 今回の実験は一般性を有
すると考えられる。図から，両燃料とも火炎伸張率が増 加するにつれて着火しにくくなっている，これは,火炎伸 張が増加すると拡散が支配的になるため着火しにくくな ったと考えられる.また，この実験においても実験 II 同様にDMEより $\mathrm{C}_{3} \mathrm{H}_{8}$ のほうが着火しやすいことが確認さ れた。

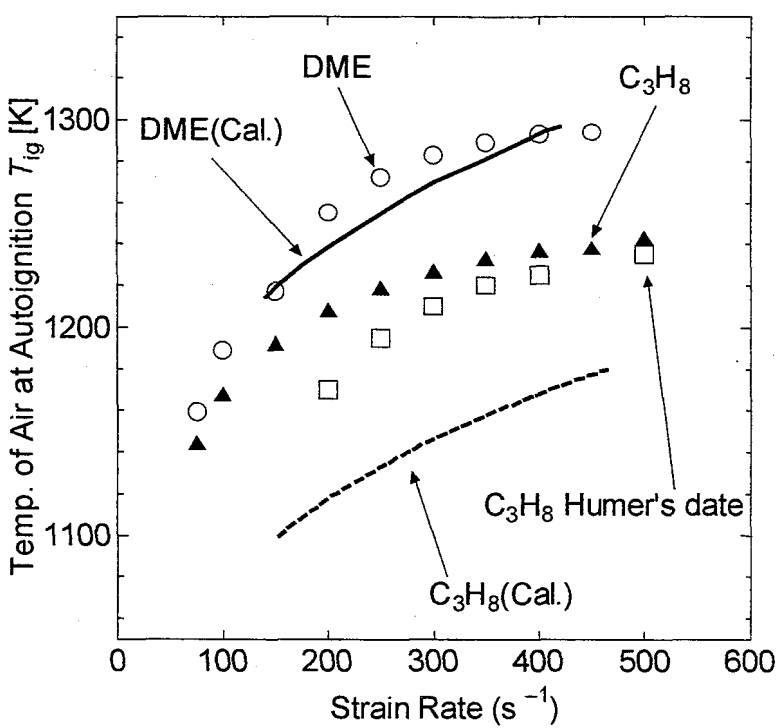

Fig. 3 The temperature of air at autoignition, $T_{\mathrm{ig}}$, as a function of the strain rate.

4. 結論

(1)不活性ガス $\mathrm{N}_{2}$ を $\mathrm{CO}_{2}$ に置換した混合気を用いて実験を 行い比較した結果, $\mathrm{CO}_{2}$ 希釈の場合が消炎しにくいこと が分かった。これは $\mathrm{CO}_{2}$ で希釈することで混合気の温 度伝導率が低下し火炎伸張を受けた場合の温度低下が 小さくなるためと推察される.

(2)DME と $\mathrm{C}_{3} \mathrm{H}_{8}$ の着火を比較すると, 燃料の質量分率が 等しい場合，もしくは火炎伸張率が等しい場合，DME より $\mathrm{C}_{3} \mathrm{H}_{8}$ の方が着火しやすいことが分かった。一般に $\mathrm{C}_{3} \mathrm{H}_{8}$ より $\mathrm{DME}$ の方が自着火温度が低いことが知られ ているが，非一様流中では拡散の影響により $\mathrm{C}_{3} \mathrm{H}_{8}$ が着 火しやすい結果となった。

\section{参考文献}

(1) Heywood, J.B., Internal Combustion Engine Fundamentals, McGraw-Hill, 930p, 1988. (2) Bradly, D., Lawes, M., and Sheppard, C.G. W., Proc. Instn. Mech. Engrs., Vol.214, PartC, p.257-268, 2001. (3) Takagi, Y., Proc. Combust. Inst. 27, p.2055-2068, 1998. (4) Kajitani, S., JSME TED Newsletter, No.42, 12p, 2004. (5) B. J. Hansen, et al., Soc. Am. Engrs. Paper SAE-950063. (6) Larson, E. D. Tingjin R., Energy Sustain, Develop. VII(4), p.2-44, 2003. (7) Humer, S., Seiser, R. and Seshadri, K., Proc. Combust. Inst., Vol.29, p.1597-1607, 2002. (8) Seiser, R., Ph. D Thesis; Technical University of Graz, 2000. (9) Payer, W., Diploma Thesis, Vienna University of Technology, 2002. (10) Geieregger, M., Diploma Thesis, Vienna University of Technology, 2003. (11) Seshadri, K. and Williams, F.M., Int. J. Heat Mass Transfer21, p.251-253, 1978.

(12) Chen, R., Axelbaum, R.L., Combust. Flame, 142, p.62-71, 2005. (13) Nishioka, M., Law, C.K., Takeno, T., Combust. Flame, 104, p.328-342, 1996. (14) Kee, R.J. Rupley, F.M., and Miller J.A. et al., CHEMKIN Collection, Release3.7, Reaction Design, Inc., San Diego, CA, 2003. (15) Kaiser, E.W., et al., Int. J. Phys. Chem. 3A104, p.8194-8206, 2000. 